\title{
Mygalomorph spiders of the southern Carnarvon Basin, Western Australia
}

\author{
Barbara York Main ${ }^{1}$, Alison Sampey ${ }^{23}$ and Paul L.J. West ${ }^{2,4}$ \\ ${ }^{1}$ Department of Zoology, University of Western Australia, Nedlands, \\ Western Australia 6907, Australia (for correspondence) \\ ${ }^{2}$ Department of Terrestrial Invertebrates, Western Australian Museum, \\ Francis Street, Perth, Western Australia 6000, Australia \\ ${ }^{3}$ Lot 1984 Weller Road, Hovea, Western Australia 6071, Australia \\ ${ }^{4}$ current address: Halpern, Glick and Maunsell Pty Ltd, \\ 629 Newcastle Street, Leederville, Western Australia, 6007, Australia
}

\begin{abstract}
Nineteen genera belonging to seven families were recorded during a systematic survey of mygalomorph spiders in the southern Carnarvon Basin, a region on the central coast of Western Australia. The study was based on collections of predominantly male specimens collected from pitfall traps. Of the 60 species distinguished, 55 were undescribed. Patterns in the species composition of assemblages conformed with the gradient in wettest quarter precipitation, although localised patterns of endemism were also apparent. Species richness at quadrats exceeded that of many other habitats in Western Australia. Seasonal occurrence of wandering males (phenology) agreed with that known for respective genera in other regions, particularly of the predominantly winter breeding Idiopidae. Unusually large numbers of specimens were collected of some small-bodied nemesiids (over 70 specimens at some quadrats); this indicates an extraordinary population density possibly comparable to patches in some mesophytic forests.
\end{abstract}

\section{INTRODUCTION}

Mygalomorph spiders (trapdoor spiders) of the central and northern regions of Western Australia are poorly known. Very few specimens have been collected relative to southern areas of the state, such as the wheatbelt, goldfields, southern coastal and forest regions. Although the Western Australian Museum and Barbara York Main collections (the latter held in the Department of Zoology, University of Western Australia) contain some specimens from the southern Carnarvon Basin region, only a few of these are documented in the literature. Main (1990) listed representatives from the four families: Barychelidae, Idiopidae (as Ctenizidae), Dipluridae and Nemesiidae. These taxa comprised seven genera and at least eight species of which only one, Aname diversicolor (Hogg), could be positively identified as a named species.

This paper reports the results of the first systematic survey of mygalomorph spiders in the southern Carnarvon Basin, an arid to semi-arid region on the mid-western coast of Western Australia.

\section{MATERIALS AND METHODS}

\section{Study Area and Field Collecting}

The study area of the southern Carnarvon Basin, embracing Shark Bay and associated peninsulas, comprises $75000 \mathrm{~km}^{2}$ in the mid west coastal region of Western Australia from the Minilya River in the north to the Murchison River in the south and eastwards to the vicinity of Gascoyne Junction (Figure 1). The physical features of the study area (including the specific quadrats sampled) (see Appendix 1) are described more fully by Wyrwoll, Courtney and Sandercock (2000) and Wyrwoll, Stoneman, Elliott and Sandercock (2000). Biogeographically, the study area covers the southern half of the Carnarvon District of the Eremaean Province and the northern end of the Irwin District of the Southwestern Province (Beard, 1980). It spans a wide climatic zone across the transition from tropical arid (with summer rainfall) in the north to temperate semi-arid (with mainly winter rainfall) in the south. The vegetation of this area is described by Keighery et al. (2000).

A total of 63 quadrats were sampled. Quadrats were positioned so that the study area's main geomorphic units were sampled, and widespread surface-types were sampled across the geographic extent of the study area. For logistical reasons, quadrats were clustered (in groups of two to six) around the 13 'campsites' indicated in Figure 1. Coordinates of individual quadrats appear in Appendix $\$ \$ \$$ (this volume). Names and coded initials of campsites were $\mathrm{BO}$, Boolathanna 


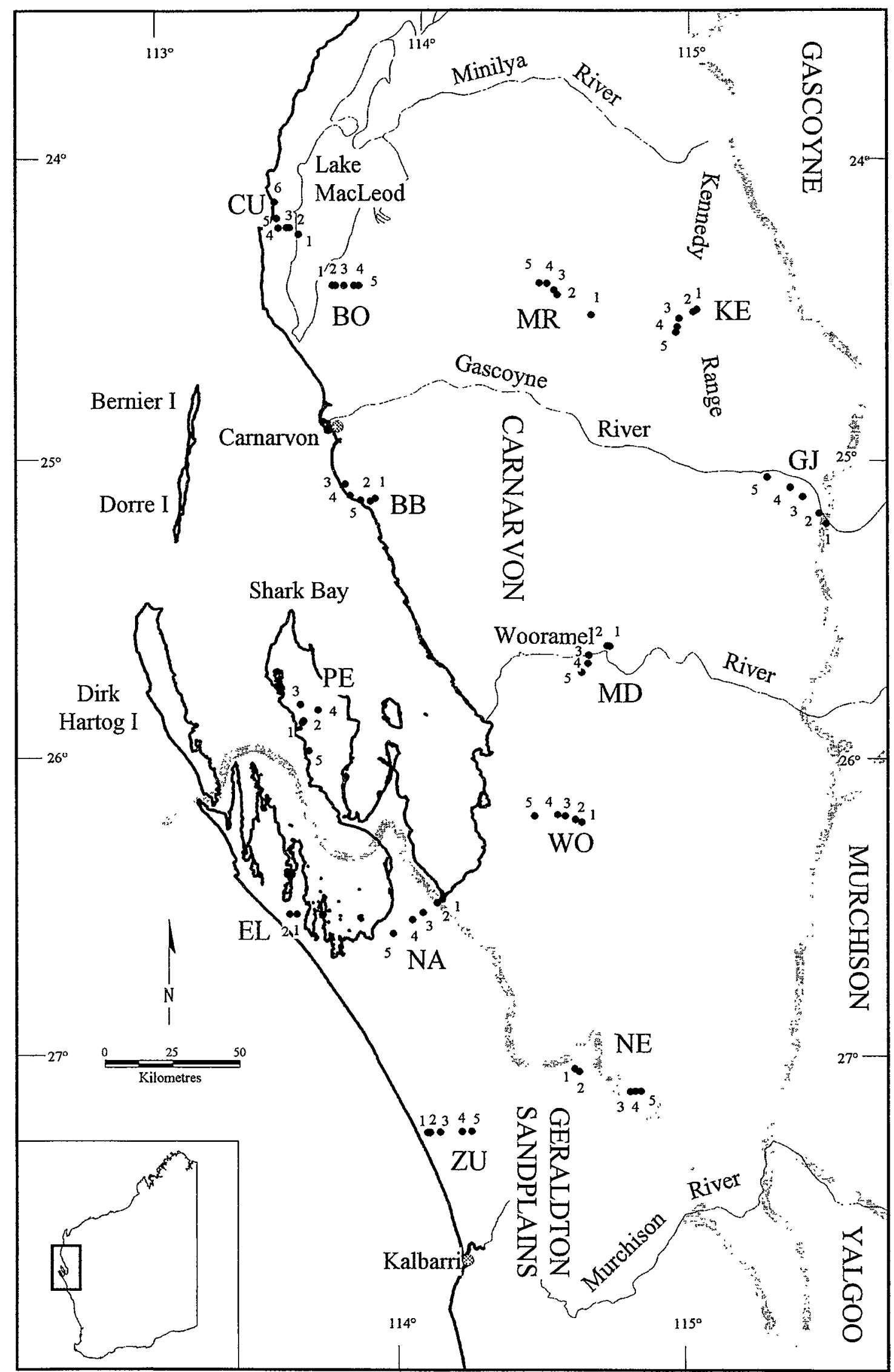

Figure 1 Map of the study area, showing campsites (upper case letters) and their associated quadrats (numbers). Names of camp sites: BO, Boolathanna Pastoral Lease; BB, Bush Bay; CU, Cape Cuvier; EL, Edel Land: GJ, Gascoyne Junction; KE, Kennedy Range; MD, Meedo Pastoral Lease; MR, Mardathuna Pastoral Lease; NA, Nanga Pastoral Lease; NE, Nerren Nerren Pastoral Lease; PE, Peron Peninsula; WO, Woodleigh Pastoral Lease; ZU, Zuytdorp. Half tone lines indicate phytogeographic district boundaries (Beard, 1980). 
Pastoral Lease; BB, Bush Bay; CU, Cape Cuvier; EL, Edel Land; GJ, Gascoyne Junction; KE, Kennedy Range; MD, Meedo Pastoral Lease; MR, Mardathuna Pastoral Lease; NA, Nanga Pastoral Lease; NE, Nerren Nerren Pastoral Lease; PE, Peron Peninsula; WO, Woodleigh Pastoral Lease; ZU, Zuytdorp.

A line of five 'wet' invertebrate pitfall traps (each five metres apart) was set on each quadrat, and left open for 12 months (114 000 trap-nights). Traps were $300 \times 400 \mathrm{~mm}$ buckets, sunk into the ground five metres apart, and partially filled with a solution of glycol-formalin (see Harvey et al., 2000). A sheet of wire mesh (10 mm square holes) was suspended 5 to $7 \mathrm{~cm}$ below the mouth of each bucket to act as a filter and minimise accidental vertebrate deaths, although a $20 \mathrm{~mm}$ gap was left between the edge of the mesh and the wall of the bucket. Finally, a lid perforated with five holes, each $5 \mathrm{~cm}$ in diameter, was placed over the mouth of the bucket. Traps were opened in August 1994 and cleared every three months in September/ October 1994, January 1995, May/June 1995 and August/September 1995 when they were removed. Small numbers of mygalomorphs were also retrieved from trap-arrays (referred to here as 'dry' traps) set for vertebrates on the same quadrats (see McKenzie et al., 2000).

In the field, specimens from pitfall traps were strained from the ethylene-glycol and transferred to $75 \%$ alcohol. In the laboratory, they were washed in water and stored in $75 \%$ alcohol. A. Sampey and P.J.L. West then separated the Mygalomorphae from the rest of the invertebrates, and bulk-stored this material according to quadrat.

\section{Sampling Scope and Constraints}

Mygalomorph spiders are mostly sedentary and fossorial, particularly in seasonally arid areas; most live out their entire life cycle within the one burrow. Females and juveniles generally do not forage or wander away from their burrows but adult males vacate the burrow in search of females and may wander relatively long distances (Main, 1985). Pitfall trapping is a proven method of capturing males, of which most species are highly seasonal and hence available only for short periods of the year. Sampling of all species within a prescribed area is generally assured if traps are left open for at least a year (Main, 1996; B.Y. Main, unpublished records) as in the present survey. However, the wire-mesh filter and narrow openings used in the pitfall traps, reduced the chance of capturing large spiders, and few of the very large species which could have been expected to be in the region were collected. For example, very large specimens of Aname (Nemesiidae), Aganippe, Anidiops and Gaius (Idiopidae), Barychelidae and Theraphosidae were not collected.
Very few specimens were collected by hand, so virtually no data were obtained on burrows, prey or microhabitats. The broad biology of spiders discussed herein is inferred, mainly by extrapolating from data on the biology of the respective genera in other parts of their geographic range.

\section{Taxonomic Approach and Coverage}

All mygalomorph specimens were assigned to families, then genera and, sequentially, to specieslevel by B.Y. Main. The families Actinopodidae, Barychelidae, Ctenizidae, Idiopidae and Theraphosidae were sorted to generic and species level. Within the Nemesiidae, the genera Teyl, Chenistonia and three undescribed genera were sorted to species-level, but the equivalent speciesanalysis of the Aname and Kwonkan (both highly speciose genera) is not yet complete. Similarly Cethegus (family Dipluridae) requires further analysis.

\section{Data Analysis}

The data matrix comprised only the presence and absence of species on each quadrat. The computer package PATN (Belbin, 1993) was used to explore the data matrix for patterns in species composition. Quadrats with less than 2 species were excluded (CU1, PE1 and GJ4). The Czekanowksi association measure was used to compare quadrats for similarities in species composition, and the 'Two-step' association measure was used to determine the quantitative relationship between each pair of species. The structure of the resulting association matrices was displayed as dendrograms using a modified 'unweighted pair group arithmetic averaging' (UPGMA) hierarchical clustering strategy (Sneath et al., 1973), and the data matrix re-ordered accordingly, as a two-way table.

The biological patterns revealed by these analyses were investigated in terms of a set of attributes related to the physical environments of the quadrats (Wyrwoll, Stoneman, Elliott and Sandercock, 2000), utilising the group statistics module (GSTA) in PATN, and assessed statistically with Kruskal-Wallis K-sample tests. Eleven climatic attributes were derived for each quadrat using ANUCLIM (McMahon et al., 1995). Soil and geomorphic attributes were also recorded from each quadrat (Wyrwoll, Courtney and Sandercock, 2000). The 17 soil chemical and texture values used herein were derived from sub-samples collected at a depth of $5-10 \mathrm{~cm}$ from 20-30 regularly dispersed points on each quadrat, then bulked (Appendix D). Significant correlations between these physical attributes were identified using Kendall's rank correlaton coefficient (Kendall's tau). Physical attribute names and codes are listed in Appendix 2. 


\section{RESULTS AND DISCUSSION}

\section{Specimens Collected}

A total of 1332 specimens were examined: 1136 males, 44 females and 152 juveniles. These figures exclude a large number of Kwonkan and Aname specimens that have been partially sorted as 'morphospecies', but include Aname diversicolor (Hogg). Although most of the specimens were taken from the wet (invertebrate) pitfall traps, 111 specimens were from dry (vertebrate) pitfall traps (97 males, 1 female and 13 juveniles).

\section{Systematics}

Nineteen genera and more than 60 species have been identified from the seven families represented in the southern Carnarvon Basin (Tables 1 and 2). This includes all but one of the families of mygalomorphs found in Western Australia. The few Barychelidae specimens collected have been conservatively allocated to two genera but possibly represent more. Within the Nemesiidae, species identification of the Kwonkan and Aname specimens is incomplete; there are probably four or more species of Kwonkan and at least 13 Aname species. Within the Dipluridae there is doubt about the species identity of some Cethegus specimens, which may represent two or more species. Within the Nemesiidae there is some confusion also between Nemesiidae Genus 1 sp. 2 and Aname sp. 3. However the remaining species allocations have been made with a high degree of confidence.

Only five species could unequivocally be attributed to named species: Aganippe occidentalis Hogg (Idiopidae), Gaius villosus Rainbow

Table 1 Genera and species identified from each family of Mygalomorphae.

\begin{tabular}{lll}
\hline Family & Genus & No. of species \\
\hline Actinopodidae & Missulena & 4 \\
Barychelidae & Idiommata & 1 \\
& Synothele & 1 \\
Ctenizidae & Conothele & 7 \\
Dipluridae & Cethegus & 1 or 2 \\
Idiopidae & Aganippe & 3 \\
& Anidiops & 1 \\
& Arbanitis & 6 or 7 \\
& Eucyrtops & 7 or 8 \\
& Gaius & 1 \\
Nemesiidae & Idiosoma & 1 \\
& Aname & 13 \\
& Chenistonia & 1 \\
& Genus 1 & 2 \\
& Genus 2 & 1 \\
& Kwonkan/Yilgarmia & 3 \\
& Teyl & 4 \\
Theraphosidae & Kwonkan & $?$ (unsorted) \\
& Selenocosmia & 1 \\
\hline
\end{tabular}

(sometimes attributed to Anidiops) (Idiopidae), Idiosoma nigrum Main (Idiopidae), Aname diversicolor (Hogg) (Nemesiidae), and Selenocosmia stirlingi Hogg (Theraphosidae). Several of the unnamed species have been collected previously from other localities, but many appear to be endemic to the region.

The three undescribed genera are all from the Nemesiidae. The genus 'Kwonkan/Yilgarnia' was previously known, having been collected by B.Y. Main in the Gascoyne region and it is also represented in the Western Australian Museum collections. However, both Nemesiidae Genus 1 and Genus 2 were unknown previously.

\section{Ecology and Biogeography}

\section{Assemblage Richness}

Specimens that could not be determined (labelled 'sp. indet.' in Table 2) are ignored in the analysis if there was a possibility of confusion with congenerics. For instance, they counted towards the species richness totals if no con-generic was recorded at the same quadrat. An average of 5.9 (s.d. = 2.8) species of 4.5 genera (s.d. $=1.9$ ) were recorded from the 63 quadrats. Up to 11 species were found on the same quadrat, with more than seven species at $25 \%$ (16) of the 63 quadrats. This exceeds assemblage richness values observed in most other regions of Western Australia, where six is usually the maximum, and seven is very rare (Main, 1976, p. 50).

However, the methodology relating to sampling area on which these assessments are based are different. It is possible that along the Carnarvon Basin pit lines a diversity of microhabitats was represented, thus accounting for the relative species richness. The earlier studies (Main, 1976) referred to burrows in close proximity in relatively homogeneous habitats (microhabitats) with recognition that in the surrounding broader generalised habitat additional species were present. For example, in a heath/shrubland/mallee locality at Durokoppin in the wheatbelt, 25 species were found along five transects $100 \mathrm{~m}$ apart (Main, 1996). At this locality sampling was made from three pit traps of $12 \mathrm{~cm}$ diameter placed five metres apart on each transect. The pits were left open continuously for five years and cleared five or six times each year. Species of such assemblages mostly occupy different microhabitats or, if co-occurring in the same microhabitat, exhibit distinctive behaviouràl differences (Main, 1976, 1996).

\section{Species Richness in Relation to Habitat and Biogeography}

In summary, the richest quadrats are in the part of the study area that is dominated by winter rainfall, and are either coastal or in the transitional vegetational zone of the Southwest and Eremaean 


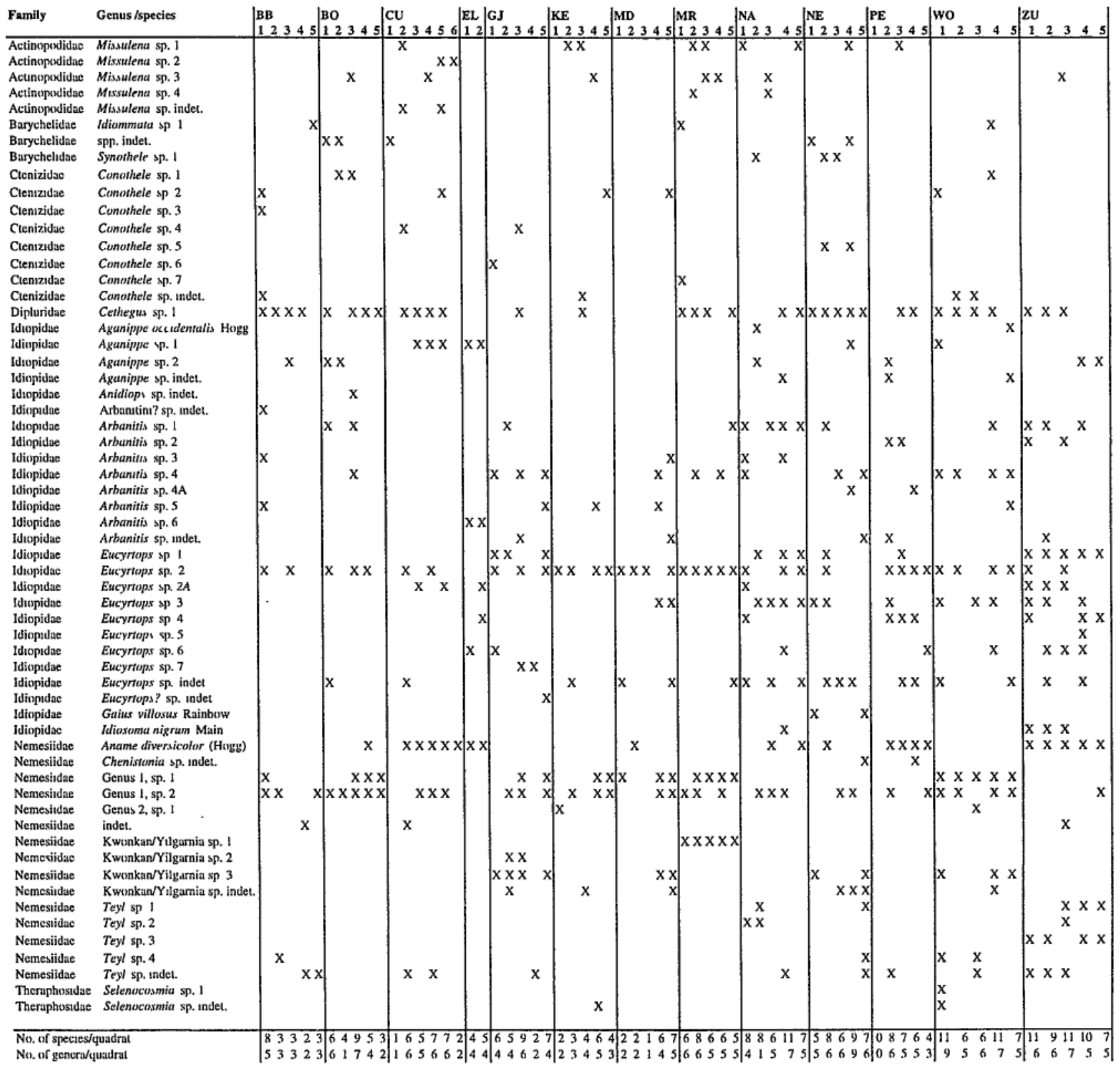

Table 2 Site occurrences (quadrats) of mygalomorph species. All occurrences are for male specimens except where listed as sp. indet. (indeterminate species) which indicates female or juvenile specimen(s). Apart from remarks on juvenile dispersion, in the text and computer analyses, indeterminate species are only considered if there are no identifiable con-generics at the same site. See text and Figure 1 for full names of campsites.

Botanical Provinces (Beard, 1976, 1980, 1990). This equates to the earlier recognised Mulga/Eucalypt Line (see Gardner, 1944, pp. li, lii, Plate X; Serventy and Whittell, 1951).

Two of the three poorest quadrats (PE1, 0 species; CU1, 1 species) were in low shrublands of samphire growing on saline pans. In the wheatbelt and eastern goldfields regions elsewhere in Western Australia, this habitat is only favoured by a few relictual Teyl and Arbanitis, which occur on the fringes of salt lakes that form part of the ancient drainage systems. However, other saline pan quadrats in the Carnarvon Basin were richer in species and genera including:
- Missulena sp. 1, three species of Eucyrtops, three species of Arbanitis and Teyl sp. 2 at NA1,

- Conothele sp. 1, Aganippe sp.2 and Nemesidae Genus 1 sp. 2 at $\mathrm{BO} 2$ and

- an Aganippe and an Eucyrtops at BB3.

Possibly all these species have remained from earlier habitats that have been transformed by coastal samphire encroachment associated with historical changes in sea level. The other speciespoor quadrat (MD3, with 1 species) was on a river bank frequently scoured by floods.

Most of the southern quadrats were richer than average, having an average of $7.6(\mathrm{~s} . \mathrm{d} .=2.8)$ species 
per quadrat. The heath and shrubland quadrats at the southern end of the study area were the richest; ZU1-ZU5 (12, 10, 12, 10 and 7 species, respectively) and also had the greatest number of Eucyrtops species $(5,4,3,5$ and 2 species, respectively). This pattern suggests speciation in relation to heterogeneity of habitats. In the wheatbelt region to the south, shrublands and heaths (with a diversity of microhabitats) are also species rich for mygalomorphs (Main, 1996). The richness at these southern Carnarvon Basin quadrats also can be explained by the overlap of

- northern (historically tropical) genera such as Conothele and Cethegus (see Main, 1997),

- widespread continental genera such as Missulena and/or

- genera which occur on both sides of the continent, but are absent from the central region such as Arbanitis, with

- southern genera (i.e. of the wheatbelt and goldfields) such as Eucyrtops, and the widespread southern species Aname diversicolor.

When the rest of the Aname and Kwonkan specimens are sorted, several of these quadrats may prove to be even richer in species. ZU3 was in the most mesic habitat in the study area (see Smith and McKenzie, 2000), which could account for the occurrence of Idiosoma nigrum, a southern species typical of the central and northern wheatbelt (see elsewhere this paper).

Species richness of mygalomorphs over the whole of the region is greater than that for centipedes and scorpions but lower than araneomorph spiders. This pattern for the dominant terrestrial arthropod predators (i.e. apart from certain insect groups such as carabid beetles) is similar to that of other regions.

\section{Habitat preferences and edaphic constraints}

At the generic level and sometimes family level, mygalomorphs are partly habitat restricted according to soil structure. Morphological characteristics determine whether spiders can dig in particular soil types. For example, ctenizids (Conothele) and idiopids have a rake of teeth on the apical angle of the chelicerae which enables the spiders to dig in loamy, heavy clay and strongly compacting soils. In contrast, the Dipluridae (Cethegus), many nemesiids, some barychelids and theraphosids lack a rastellum and such spiders are confined to sandy, loose or friable soils. Although Missulena (Actinopodidae) has a pronounced rastellum, the genus occurs in a range of soil types from sand to heavy clay. As well as this relationship between morphology and soil preference, certain behavioural characteristics also restrict some genera to particular soils. Teyl species rarely use silk to line their burrows hence occur only in relatively coarse and angular grained soils in which the burrow walls are self supporting. Within other environmental parameters such as climatic seasonality, the spiders are thus further restricted to habitat types.

\section{Patterns in the Species Composition of Assemblages}

In Figure 2 the data have been re-ordered according to the quadrat and species classification analyses. When the quadrats were classified according to similarities in their species composition, the dendrogram partitions at the twogroup level could be characterised in terms of differences in their climatic attributes. 'Coldest Quarter Precipitation' provided the best separation of the two groups. In contrast, the structure of the dendrogram derived from the species classification was the only basis used to partition the 49 species in the data matrix into 12 clusters (A-L); unfortunately, detailed ecological data on the mygalomorph spiders of the region are too scant to provide an extrinsic rationale for this partitioning decision.

Three distinct types of species-cluster were apparent in Figure 2. Two were related to ecological or biogeographical gradients, and one to the strongly localised patterns of occurrence in their component species. Species clusters $\mathrm{J}$ and $\mathrm{K}$ comprised species that were widespread in the study area. Clusters A to I and cluster L comprised species with strongly localised distributions in the study area, or occurred sporadically. Their sparsity may have been exacerbated by sampling noise introduced by the mesh filters used to minimise vertebrate captures. Six (or seven) of the 27 species that comprise these clusters are (as adults) very large species (Aganippe occidentalis, Aganippe sp.1, Anidiops sp. indet., Chenistonia sp. indet., Gaius villosus and Selenocosmia sp. 1 and sp. indet.), whereas only one (Aname diversicolor) of the 22 species in Assemblages $\mathrm{J}$ and $\mathrm{K}$ was large, and it has relatively short, slender legs. It may also be an artifact of unresolved taxonomic problems and incomplete sorting of some families.

Wettest quarter precipitation provided the best separation of the 2 quadrat-groups defined in Figure 2, although the gradient in 'soil carbon' also conformed with the dendrogram structure at this level (Figure 3). A similar result was found by Harvey et al. (2000) for ground-dwelling araneomorph spiders collected during this survey. In a dry region such as the Carnarvon Basin, a correlation between rainfall and leaf-litter would be expected. The sensitivity to dessication of mygalomorph spiders is relevant here (see Main, 1997).

\section{Sympatry of Congenerics}

A notable taxonomic/biological relationship is manifested in the high degree of sympatry amongst congenerics, particularly in the following genera (Table 2): Missulena (three quadrats ' with two 


\section{Quadrat Group:}

\section{Species Cluster}

A*Aganippe sp 1 Conothele sp 2

* Selenocosmia sp I Teyl sp 4

B Arbanitis sp 4A Conothele sp 5

C*Chenistonia sp indet.

*Gaius villosus

D Axbanitis sp 6 Missulena sp 2

$\mathbf{E *}$ Aganippe occidentalis Synothele sp 1

$\mathbf{F}$ Anidiops sp indet. Conothele sp 1 Idiommata sp 1 Genus 2 sp 1 Conothele sp 7 'Kwonkan/Yilgarnia' sp 1 Missulena sp 4

G Arbanitis sp 5

* Selenocosmia sp indet. Conothele sp 3

H Conothele sp 4 Eucyrtops sp 7 'Kwonkan/Yilgarnia' sp 2

I Conothele sp 6

J Arbanitis sp 3 Arbanitis sp 4 Genus 1 sp 1

'Genus 1 sp 1 'Kwonkan/Yilgarnia' sp 3 Cethegus sp 1 Eucyxtops sp 2 Genus 1 sp 2 Missulena sp 1 Missulena sp 3

K Aganippe sp 2 Tey 1 sp 1 Teyl sp 2

* Aname diversicolor Eucyrtops sp 2A Eucyrtops sp 4 Arbanitis sp 2 Idiosoma nigrum Teyl sp 3

Arbanitis sp 1 Eucyrtops sp 3 Eucyrtops sp 1 Eucyrtops sp 6

I Eucyrtops sp 5

2

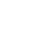

\section{Quadrat Codes}

Group-1

Group-2

BMGWMKBWGWBWBKMMMMMBNBMBBBGGKMKMPBKNNW | CPPNZZNNZNNPZZNCCCNEEC BDJODEOOJOOOOEDRRRRBEBRBOOJJEDEDEBEEEO UEEAUUAEUAAEUUAUUUELIU $15554434314255124352351312121322543153 \mid 2344125231224533544126$
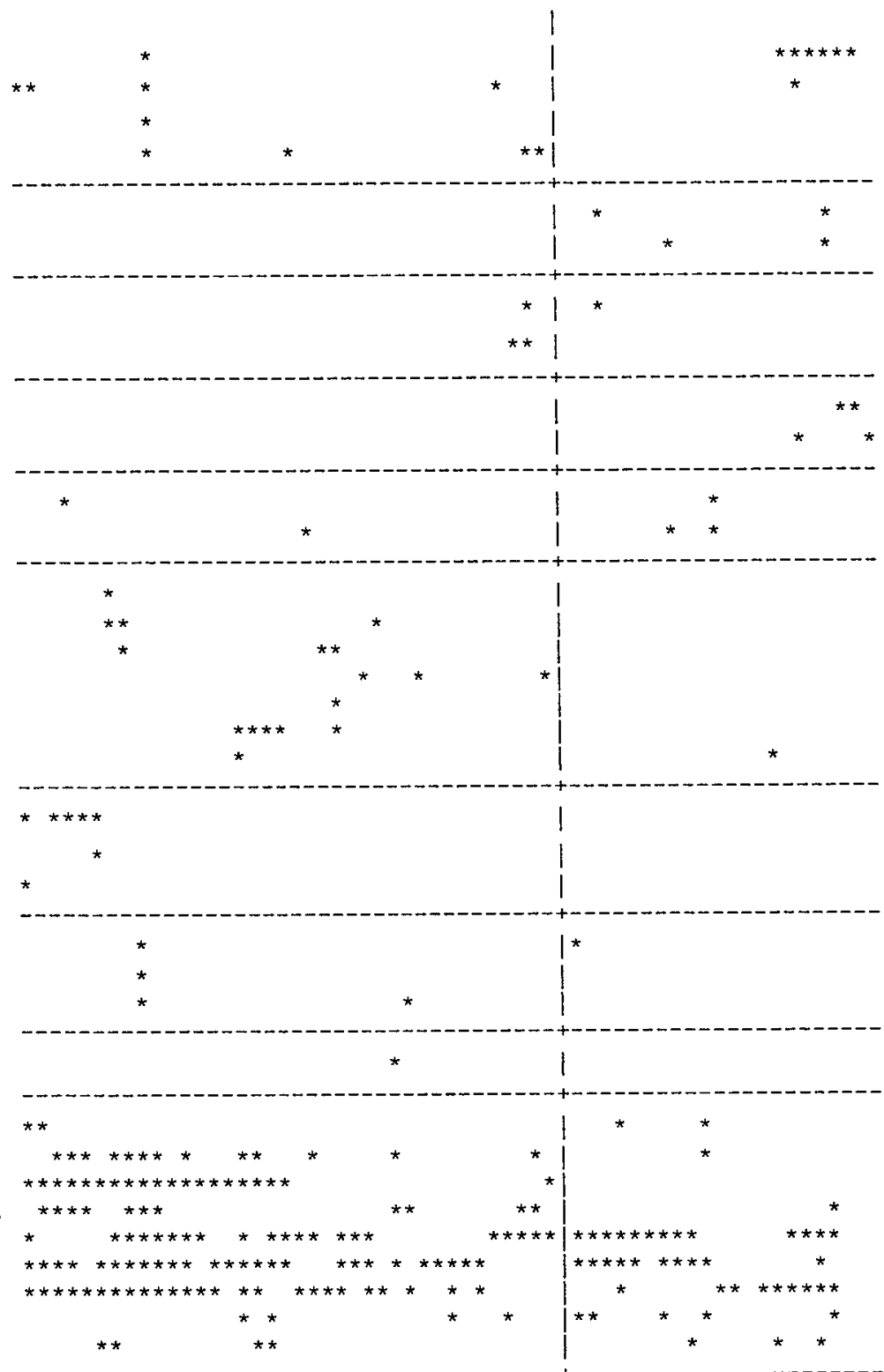

1

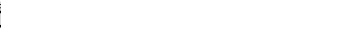

\section{(20.9)}


species); Conothele (one quadrat with two species); Aganippe (one quadrat with two species); Arbanitis (eight quadrats with two species, one quadrat with three species); 'Kwonkan/Yilgarnia' (two quadrats with two species). However the genus with the highest degree of sympatry is Eucyrtops with 16 quadrats with two or three species, three quadrats with four species and two quadrats with five species. It is also perhaps noteworthy that Conothele and Eucyrtops, each with seven species, are the two most speciose genera (apart from Aname of which the 13 species are not fully documented here). Nevertheless, Conothele has a low level of sympatry (only one quadrat with two species). On the other hand, Conothele is also fairly habitat-specific as a genus and does not exhibit the adaptive plasticity (Main, 1997 and unpublished data) of some other genera with which it occurs, hence restricting the possibility of multiple sympatry.

\section{Endemism and Extension of Known Geographic Ranges}

The general life history constraints of most mygalomorph spider species, such as sedentary life style, fidelity of burrow site and poor dispersal powers (Main, 1976, 1978, 1985, 1987), mean that restricted geographic distributions and high endemism can be expected. Individual spiders of all but a few genera, e.g. the web weaving Cethegus which moves burrow site after rain (Main, 1992), live out their entire lives in the one burrow which is enlarged as the spider grows (Main, 1976, 1978, 1985). Cethegus, Missulena and Conothele are the only known aerial dispersers amongst the genera represented in the southern Carnarvon Basin. However, dispersal distance of juveniles of these genera is likely to be short, possibly less than $100 \mathrm{~m}$ (B.Y. Main unpublished data).

The only species collected from a single quadrat were Conothele sp. 3, sp. 6 and sp. 7 from BB1, GJ1 and MR1 respectively, and Eucyrtops sp. 5 from ZU4. Conothele sp. 6 and sp. 7 are also notable as the only singletons (single specimens of a species from the whole collection). Although Selenocosmia sp. 1 was found only at WO1, the immature specimens (sp. indet. from other localities) are almost certainly the same species.

The most noteworthy range extension is that of Idiosoma nigrum. Formerly, it was not known to occur north of the Murchison River. The genus Arbanitis, although known from south-east of the study area and also from Dirk Hartog Island, has been collected only rarely from so far north in Western Australia. The wide occurrence of Eucyrtops (a southern genus) in the study area also extends its known distribution as it was not previously known from north of the Gascoyne River. The occurrence of the other southern genus, Teyl, as far north as the BB campsite is surprising because its foraging, dispersal and reproductive behaviour is considered to be tied to winter rainfall (see below). This suggests a relictual occurrence with persistence dependent on the occasional seasons during which autumn/early winter rain is experienced.

\section{Phenology of Genera and Species}

Wandering of adult male mygalomorphs is associated with humid weather either prior to or during rainy periods. Most species and even genera show marked seasonal preferences. Figure 3 indicates a general relationship between winter rainfall and the composition of mygalomorph communities. Figure 4 shows the actual dates of collection (which reflect the wandering periodicity of male specimens). Of the genera represented in the study area, those with known wide continental ranges, such as Missulena, comprise species with distinct seasonal preferences of either summer (tropical species) or autumn/winter (southern species) wandering. Conothele, which is primarily a tropical genus (Main, 1997), has summer wandering males in tropical Australia but some "rainforest relicts" that occur in southern and desert areas (see Main, 1997) wander during winter. The present

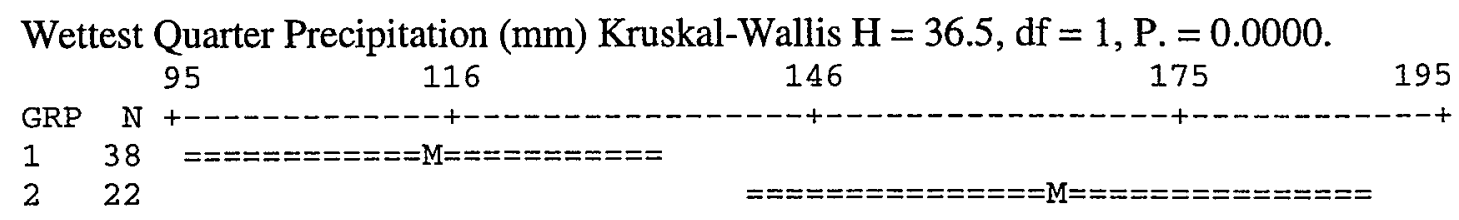

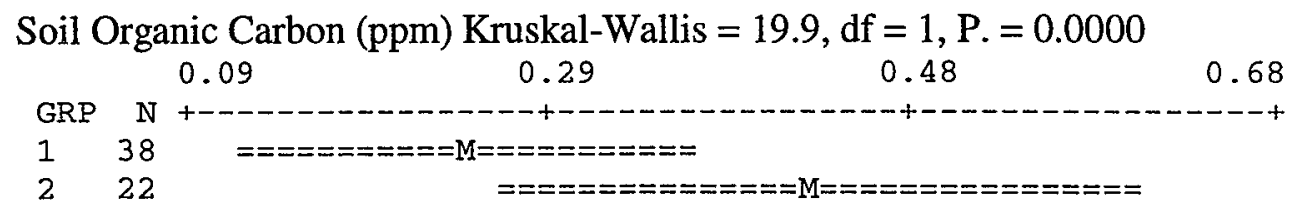

Figure 3 Average environment attribute values for the two quadrat groups defined in Figure 2. Bars indicate standard deviations about the mean (M); GRP = classification group number in Figure $2 ; \mathrm{N}=$ number of quadrats in each classification group. 
survey indicates a predominantly summer phenology for the genus Conothele but with Conothele sp. 3 a winter wanderer and several possibly opportunistic species.

Other genera reflect the pattern found in other regions where the species have a rigid seasonal phenology. The Idiopidae (Arbanitis, Idiosoma, Eucyrtops and Aganippe) and the nemesiid genus Teyl are all obligate autumn/winter/early spring wanderers (depending on the onset of autumn/ winter rain). In contrast Cethegus [another tropical genus; see Main (1997)] is seasonally opportunistic. Gaius villosus, although generally an autumn wanderer has been shown elsewhere to run at the first opportunity which can be instigated by a summer thunderstorm (see Main, 1987) which would appear to be the case here. Grey areas in the bars of Figure 4 indicate anomalies in wandering times which are a result of trap duration/clearance times. For example some Eucyrtops species show as late summer wanderers whereas the spiders were probably captured at the end of the pit period, i.e. with an early autumn rain in those pits that were not cleared between January and May.

\section{Dispersion of Juveniles}

Juveniles that could not be attributed to a genus, and Aname and Kwonkan specimens are not considered here. No specimens of Gauis, or Nemesiidae Genus 2 were collected. Of the other genera, taking into account several possible anomalies due to clearance times of some summer/early winter samples, most genera were predominantly winter dispersers. Exceptions were
Cethegus with predominantly spring dispersion but also a few indications of late summer/possible early winter dispersion and Selenocosmia with summer dispersion [both consistent with the interpretation of Main (1997) that these genera are tropical relicts] and Genus 1 with winter/spring dispersion.

\section{Abundance and Population Density of Species}

Some measure of relative population density can be gauged from the numbers of male specimens collected from individual quadrats (see Table 3). Of particular interest are the nine species represented only by a single specimen in any quadrat: Missulena sp. 4, Synothele sp. 1, Conothele sp. 2, 3, 6 and 7, Arbanitis sp. 4A, Gaius villosus and Selenocosmia sp. 1. Low numbers of Missulena and Conothele is understandable in that both genera are aerially dispersed and the spiders do not usually aggregate. Nevertheless, Lake (1990) reported a high density of wandering Missulena males in a Brisbane locality. Gaius and Selenocosmia are both very large bodied and possibly escaped collection by the trapping procedure. At the other extreme are those species with very high numbers of spiders from particular quadrats.

Thirty-seven species were represented in at least one quadrat with two or more specimens. Sixteen species were represented by five or more specimens in quadrats (Table 3 ). Only seven species were represented in any one quadrat with more than ten specimens: Eucyrtops sp. 1 and 2, Nemesiidae Genus 1 sp. 1 and 2, and Nemesiidae Genus 2 sp. 1, Kwonkan/Yilgarnia sp. 3 and Teyl sp. 1. Of these

Table 3 Number of quadrats with five or more male specimens of respective species.

\begin{tabular}{|c|c|c|c|c|c|c|c|c|c|}
\hline \multirow[t]{2}{*}{ Species } & \multicolumn{9}{|c|}{ Number of specimens } \\
\hline & $5-10$ & $11-20$ & $21-30$ & $31-40$ & $41-50$ & $51-60$ & $61-70$ & $71-80$ & $80+$ \\
\hline Missulena sp. 2 & 1 & & & & & & & & \\
\hline Cethegus sp. & 5 & & & & & & & & \\
\hline $\begin{array}{l}\text { Arbanitis sp. } 1 \\
\text { Arbanitis sp. } 2 \\
\text { Arbanitis sp. } 4\end{array}$ & $\begin{array}{l}2 \\
1 \\
2\end{array}$ & & & & & & & & \\
\hline $\begin{array}{l}\text { Eucyrtops sp. } 1 \\
\text { Eucyrtops sp. } 2 \\
\text { Eucyrtops sp. } 2 \mathrm{~A} \\
\text { Eucyrtops sp. } 6\end{array}$ & $\begin{array}{l}2 \\
6 \\
1 \\
1\end{array}$ & $\begin{array}{l}1 \\
2\end{array}$ & & & & & & & \\
\hline Aname diversicolor & 9 & & & & & & & & \\
\hline $\begin{array}{l}\text { Nemesiidae Genus } 1 \text { sp. } 1 \\
\text { Nemesiidae Genus } 1 \text { sp. } 2\end{array}$ & $\begin{array}{l}5 \\
6\end{array}$ & $\begin{array}{l}2 \\
4\end{array}$ & $\begin{array}{l}1 \\
1\end{array}$ & 2 & & & 1 & 1 & 1 \\
\hline Nemesiidae Genus 2 sp. 1 & & 1 & & & & & & & \\
\hline $\begin{array}{l}\text { Kwonkan/Yilgarnia sp. } 1 \\
\text { Kwonkan/Yilgarnia sp. } 3\end{array}$ & $\begin{array}{l}1 \\
2\end{array}$ & 1 & & & & & & & \\
\hline Teyl sp.1 & 1 & & 1 & 1 & & 1 & & & \\
\hline
\end{tabular}




\begin{tabular}{|c|c|c|c|c|c|c|c|c|c|c|c|c|c|}
\hline Clearance dates: & W = wet pits & $\frac{\operatorname{San} .}{\mathrm{W}}$ & Feb. & March & April & $\frac{\text { Dlay }}{\text { wwy }}$ & $\begin{array}{l}\text { June } \\
\text { w }\end{array}$ & July & Aug & TSeph & $\frac{\text { Oc1. }}{\text { nowww }}$ & Nay. & Dec. \\
\hline & $\mathrm{D}=\mathrm{dry}$ pils & & & & & D D & & & & & D & & \\
\hline Family & Genus/species & & & & & & & & & & & & \\
\hline Actinopexlitac & Missulena sp. 1 & & & & & & & & & & & & \\
\hline Actinopodidac & Missulenut sp. 2 & & & & & & & & & & $x \times$ & & \\
\hline Actinupodidae & Missulena sp. 3 & & & & & & & & & & & & \\
\hline Actinupodidac & Mixsudena sp. 4 & & & & & & & & & & & & \\
\hline Barychelidac & Idianmuata sp. 1 & & & & & $x$ & & & & & $x$ & & \\
\hline Banychelidac & Symothele sp. I & & & & & & & & & & & & \\
\hline Crenizidac & Cemothele sp. I & & & & & - & & & & & & . & \\
\hline Cleni/zidae & Conothele sp. 2 & & & & & & & & & & & & \\
\hline Clenizidae & Conuthete sp. 3 & & & & & & & & & & & & \\
\hline Chenizithe & Conothele sp. 4 & & & & & & & & & & & & \\
\hline Clenizictace & Conothele sp. 5 & & & & & & & & & & & & \\
\hline Clenizidac & Conothele sp. 6 & & & & & & & & & & & & \\
\hline Clenizidase & Conothele sp. 7 & & & & & & & & & & & & \\
\hline Dipluridace & Cethegus sp. I & & & & & & & & & & & & \\
\hline ldiopidas & Aganippe uccidemalis Hogg & & & & & & & & & & & & \\
\hline Idiopidae & Aganippe sp. 1 & & & & & & & & & & & & \\
\hline Idiupidae & Agunippe sp. 2 & & & & & & & & & & & & \\
\hline Itliopidac & Arhanitis sp. 1 & & & & & & & & & & & & \\
\hline Letiopidase & Arbunitis sp. 2 & & & & & $\mathrm{X}$ & & & & & & & \\
\hline Llilopidae & Arlsomitis sp. 3 & & & & & & & & & & & & \\
\hline ldiopidae & Arbunitis sp. 4 & & & & & & & & & & & & \\
\hline ldivpidac & Arbanilis sp, 5 & & & & & & & & & & & & \\
\hline Idlisptutae & Arbanitis sp. 6 & & & & & & & & & & & & \\
\hline Idiupitae & Eucyrnopss sp. 1 & & & & & & & & & & & & \\
\hline ldiopidac & Encyrtops $\mathrm{sp} .2$ and $2 \mathrm{~A}$ & & & & $\cdots$ & & $\mathrm{K}$ & & & & 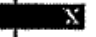 & & \\
\hline Ltopidate & Encyrtops sp. 3 & & & & & $x$ & & & & & & & \\
\hline teiopidac & Eucyrtops sp. 4 & & & & & & & & & & & & \\
\hline Lfiopidae & Euctyrtops sp. 5 & & & & & & & & & & & & \\
\hline Ldilupidac & Eucyrtops sp. 6 & & & & & & & & & & & & \\
\hline ldiopitac & Eucyrtopss sp. 7 & & & & & & & & & & & & \\
\hline ldiopidat: & Guths villosus Rainbow & & & & & & & & & & & 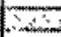 & \\
\hline Ldiopidas & Lliwsoma nigrum Main & & & & & & & & & & & & \\
\hline Nemesijdae & Antme sliversicolor (llogg) & & & & & & & & & & & & \\
\hline Nemusifdac & Genus t, sp. ! & & & & & & & & & & & & \\
\hline Nemesildae & Genus t.sp. 2 & & & & & & & & & & $\bar{x}$ & & \\
\hline Nemestidae & Genus $2, \mathrm{sp} .1$ & & & & & & & & & & & & \\
\hline Nemesiidae & Kwonkan/Yilgamia sp. 1 & & & & & & & & & & & & \\
\hline Nenc-iilae & KwonkanVYitgarnia sp. 2 & & & & & & & & & & & & \\
\hline Nemesiidase & Kwonkan/Yilgamia sp. 3 & & . & & & & & & & & & & \\
\hline Nentesiidae & Teyl sp. 1 & & m & 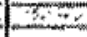 & إن & $\mathrm{x}$ & & & & & & & \\
\hline Nenesiidase & Teyl sp. 2 & & & & & & & & & & & & \\
\hline Nentesidax & $T_{y} t \mathrm{sp.} 3$ & & & & & & & & & & & & \\
\hline Nenuesiidac & $T e y l$ sp. 4 & & & & & & & & & & & & \\
\hline Theraphusidate & Selenocosmia sp. 1 & & & & Wis & {$\left[\begin{array}{c}0 \\
0\end{array}\right.$} & & & & . & & & \\
\hline
\end{tabular}

Figure 4 Phenology of species from male specimens. Because traps were cleared at more or less quarterly intervals (see text for clearance dates) the occurrence of some species appears anomalous. Data from elsewhere (B.Y. Main records) show that males generally demonstrate generic and sometimes specific seasonal wandering times. Hence the apparent anomalous occurrences recorded here are indicated in grey on the bars. Most species show a winter, a few a summer, and two possibly three, unrestricted (opportunistic) wandering times (see text for further explanation). $x=$ collected from dry pits.

only three species had more than 20 specimens in any quadrat: Nemesiidae Genus $1 \mathrm{sp} .1$ and sp. 2 and Teyl sp. 1. Two species had more than 30 specimens in some quadrats: Nemesiidae Genus 1 sp. 2 in five quadrats and Teyl sp. 1 in two quadrats; these two species also occurred in four quadrats with over 50 specimens (Teyl sp. 1 with 53 , Nemesiidae Genus 1 sp. 2 with 70, 74 and 86 specimens). Extrapolations on total population densities could be made on the basis of one male to a range of 5 to 11 females, if assuming the same sort of proportions as for the study on Anidiops (= Gaius) villosus (see Main, 1987), which could yield densities of between 265 and 583 (Teyl sp. 1) and 350-770, 370-814 and 430-946 respectively for Nemesiidae Genus 1 sp. 2. While high densities of mygalomorphs are reported for eastern species it is difficult to make direct comparisons because of the different ways of assessing densities. These have usually been based on burrows in patchily distributed microhabitats (Fairweather, 1993; Bradley, 1996) although Lake (1990) and Wishart 
(1993) considered wandering males but again in circumscribed or remnant microhabitats. Pitfall samples of male Stanwellia in both south-western Australia (Porongurup Range) and south-eastern Australia (Otway Range) suggest comparable numbers of male specimens (collections Western Australian Museum and Museum of Victoria, respectively). However, all these examples are from mesic or relatively wet sclerophyll forest rather than semi-arid sites.

Nemesiidae Genus $1 \mathrm{sp}$. 2, which is one of the two species with very high densities, i.e. over 50 specimens, is small bodied. Both species with very high densities, Nemesiidae Genus 1 sp. 2 (quadrats BO1, BO3, CU4) and Teyl sp. 1 (quadrat ZU1) are from quadrats with sandy soil and heath or low shrubland including mallee and/or hummock grassland (Triodia). The site where Teyl was collected had emergent Actinostrobus which is indicative of a relictual swamp area consistent with the habitat distribution elsewhere of Teyl in relictual "summer-dry bogs" (see Main, 1996).

\section{OVERVIEW}

The collections made during the southern Carnarvon Basin survey, with species from seven of the ten mygalomorph families found in Australia, are taxonomically and biogeographically significant. In spite of some constraints imposed by the field collecting methods, the collections give a good indication of the reproductive phenology of the species sampled, seasonal dispersion of genera and geographic range of species collected within the southern Carnarvon Basin. The collections also provide data on some extensions of known range from a southern distribution, endemicity within the region and within particular locations in the region, species richness of various sites, population abundance and, finally, relative commonness or rarity of particular species.

\section{ACKNOWLEDGEMENTS}

We are grateful to Mark Harvey for assistance with computer databasing of the spider records and for printing hand-produced tables and figures. Norm McKenzie gave valuable advice about organizing records and produced the computer generated analyses. Julianne Waldock assisted along the way with general comments and curation of specimens. We are grateful for the opportunity provided by the Department of Conservation and Land Management to participate in the survey and by the Western Australian Museum to work with the collections. Field work was carried out with funding provided by the Commonwealth through the National Reserves System Co-operative Program of the Australian
Nature Conservation Agency (now Environment Australia), together with State funds provided by the Department of Conservation and Land Management and the Western Australian Museum. Most importantly we are indebted to all those who performed the herculean task of digging the pits for the traps which yielded such a rich and fascinating lode.

\section{REFERENCES}

Beard, J.S. (1976). Vegetation survey of Western Australia Murchison 1:1000 000 vegetation series. University of Western Australia Press, Nedlands.

Beard, J.S. (1980). A new phytogeographic map for Western Australia. Western Australian Herbarium Research Notes 3: 37-58.

Beard, J.S. (1990). Plant Life of Western Australia. Kangaroo Press, Kenthurst.

Belbin, L. (1993). PATN: Pattern Analysis Package. CSIRO, Canberra.

Bradley, R.A. (1996). Foraging activity and burrow distribution in the Sydney brown trapdoor spider (Misgolas rapax Karsch: Idiopidae). Journal of Arachnology 24: 58-67.

Fairweather, P.G. (1993). Abundance and structure of fossorial spider populations. Memoirs of the Queensland Museum 33: 674-680.

Gardner, C.A. (1944). The vegetation of Western Australia. Journal of the Royal Society of Western Australia 28: xi-lxxxvii.

Harvey, M.S., Sampey, A., West, P.J. and Waldock, J.M. (2000). Araneomorph spiders from the southern Carnarvon Basin, Western Australia: a consideration of regional biogeograhic relationships. Records of the Western Australian Museum Supplement No. 61: 295321.

Keighery, G.J., Gibson, N., Lyons, M.N. and Burbidge, A.H. (2000). Flora and vegetation of the Southern Carnarvon Basin, Western Australia. Records of the Western Australian Museum Supplement No. 61: 77-154.

Lake, D.C. (1990). Observations on the eastern mouse spider Missulena bradleyi Rainbow (Mygalomorphae: Actinopodidae): natural history and envenomation. Australian Entomological Magazine 17: 93-96.

Main, B.Y. (1976). Spiders. Collins, Sydney.

Main, B.Y. (1978). Biology of the arid-adapted Australian trap-door spider Anidiops villosus (Rainbow). Bulletin of the British Arachnological Society 4: 161-175.

Main, B.Y. (1985). Mygalomorphae. In D.W. Walton (ed.), Zoological Catalogue of Australia, Vol. 3, Arachnida: 148. Australian Government Publishing Service, Canberra.

Main, B.Y. (1987). Persistence of invertebrates in small areas: case studies of trapdoor spiders in Western Australia. In D.A. Saunders, G.W. Arnold, A.A. Burbidge and A.J.M. Hopkins (eds), Nature Conservation: the Role of Remnants of Native Vegetation: 29-39. Surrey Beatty and Sons, Chipping Norton.

Main, B.Y. (1990). Spiders of the Shark Bay area, Western 
Australia. In P.F. Berry, S.D. Bradshaw and B.R. Wilson (eds), Shark Bay, Report of the France-Australe Bicentenary Expedition Committee: 231-236. Western Australian Museum, Perth.

Main, B.Y. (1992). The role of life history patterns and demography of mygalomorph trapdoor spiders for assessing persistence in remnant habitats of the Western Australian wheatbelt. Report for Project No. P150. World Wide Fund for Nature (Australia), $31 \mathrm{pp}$.

Main, B.Y. (1996). Microcosmic biogeography: trapdoor spiders in a time warp at Durokoppin. In S.D. Hopper, J.A. Chappill, M.S. Harvey, and A.S. George (eds), Gondwanan Heritage: Past, Present and Future: 163-171. Surrey Beatty and Sons, Chipping Norton.

Main, B.Y. (1997). Tropical rainforest mygalomorph spiders in the Australian desert. Memoirs of the Museum of Victoria 56: 339-347.

McKenzie, N.L., Rolfe, J.K., Aplin, K., Cowan, M. and Smith, L.A. (2000). Herpetofauna of the southern Carnarvon Basin, Western Australia. Records of the Western Australian Museum Supplement No. 61: 335360.

McMahon, J.P., Hutchinson, M.F., Nix, H.A. and Ord, K.D., (1995). ANUCLIM Users Guide, Version I. Centre for Resource and Environmental Studies, Australian National University, Canberra.
Serventy, D.L. and Whittell, H.M. (1951). A Handbook of the Birds of Western Australia. Paterson and Brokensha, Perth.

Smith, G.T. and McKenzie, N.L. (2000). Biogeography of scorpion communities in the southern Carnarvon Basin, Western Australia. Records of the Western Australian Museum Supplement No. 61: 269-279.

Sneath, P.H.A. and Sokal, R.R. (1973). Numerical Taxonomy. The Principles and Practice of Numerical Classification. W.H. Freeman, San Francisco.

Wishart, G.F.C. (1993). The biology of spiders and phenology of wandering males in a forest remnant (Araneae: Mygalomorphae). Memoirs of the Queensland Museum 33: 675-680.

Wyrwoll, K.-H., Courtney, J. and Sandercock, P. (2000). The climatic environment of the Carnarvon Basin Western Australia. Records of the Western Australian Museum Supplement No. 61: 13-27.

Wyrwoll, K.-H., Stoneman, T., Elliott, G. and Sandercock, P. (2000). The geo-ecological setting of the Carnarvon Basin, Western Australia: geology, geomorphology and soils of selected sites. Records of the Western Australian Museum Supplement No. 61: 29-75.

Manuscript received 6 December 1999; accepted 19 May 2000. 
Appendix 1 Quadrat descriptions.

Red aeolian sand plains, dunes and swales with hummock grassland and scattered shrubs to $1.5 \mathrm{~m}$ of species of genera such as Acacia, Senna, Grevillea and Eremophila: BB2, BB4, BO3-5, CU2-5, GJ2, KE1-2, MD1, 2, 4, 5, MR2-5, PE2-5, WO1-2. MD2 includes a clay plain with Acacia shrubland to $2.5 \mathrm{~m}$.

Red, yellow and greyish aeolian sandplains and dunes with low open woodlands to shrublands of species belonging to genera such as Eucalyptus, Banksia, Callitris and Acacia: EL1-2, NA2-5, NE1-5, ZU3-5. Some shallowly mantled limestone: ZU1-2.

White calcareous beach sands as dunes and plains supporting Spinifex longifolius grassland and emergent shrubs to $2 \mathrm{~m}$ : BB5, CU6.

Saline clay with surface sand supporting a samphiresaltbush shrubland to $0.3 \mathrm{~m}$ : $\mathrm{BB} 1, \mathrm{BO} 1 . \mathrm{BB} 1$ is traversed by a low red aeolian sand dune.

Saline clay with dwarf samphire shrubland to $0.4 \mathrm{~m}$ : BB3, BO2, CU1, NA1. Sometimes with gypsum: PE1.

Talus-covered hill-slopes with shallow skeletal colluvium (Kennedy and Pell Ranges) with emergent Acacia low woodland: GJ1, KE3.

Bank of the Wooramel River with mixed colluvia and
River Gums (Eucalyptus) and Acacia trees over tussock grasses: MD3.

Floodplains of the Gascoyne River:

- clay with River Gums (Eucalyptus) and Acacia shrubland over tussock grasses: GJ5,

- mixed colluvium with open Acacia shrubland over tussock grasses: GJ3,

- mixed colluvium with rock fragments, boulders and gravel common in profile and open low woodland of Acacia over Eremophila shrubs and tussock grasses: GJ4.

Eroding hill slopes of sandy clay with rock fragments with Acacia low woodland over Eremophila shrubland: KE4.

Valley floor with localised alluvial sandplain over sandy clay at depth with Acacia aneura woodland to $7 \mathrm{~m}$ : KE5.

Calcrete plateau variably and incompletely mantled by reddish to pale sands. Calcrete is abundant. Acacia shrublands to low open woodlands: WO3-5.

Undulating calcrete terrain with sand to sandy loam variably mantling calcrete supporting Acacia low open woodland to shrubland: MR1.

Appendix 2 Environmental attributes recorded at each quadrat, with codes.

\begin{tabular}{llll}
\hline Code & Attribute & Code & Attribute \\
\hline Pann & Annual average precipitation $(\mathrm{mm})$ & $\mathrm{Cl}$ & Soil chloride $(\%)$ \\
Pcld & Coldest quarter precipitation $(\mathrm{mm})$ & exNa & Exchangeable sodium $(\mathrm{me} \%)$ \\
Pwet & Wettest quarter precipitation $(\mathrm{mm})$ & $\mathrm{EC}$ & Electrical conductivity $(\mathrm{mS} / \mathrm{m})$ \\
Pwp & Wettest period precipitation $(\mathrm{mm})$ & exMg & Exchangeable magnesium $(\mathrm{me})$ \\
Pwar & Warmest quarter precipitation $(\mathrm{mm})$ & $\mathrm{N}$ & Total nitrogen (ppm) \\
Psea & Precipitation seasonality & exK & Exchangeable potassium (me\%) \\
Tann & Annual average temperature $\left({ }^{\circ} \mathrm{C}\right)$ & $\mathrm{K}\left(\mathrm{HCO}_{3}\right)$ & Available potassium $(\mathrm{ppm})$ \\
Twet & Wettest quarter mean temperature $\left({ }^{\circ} \mathrm{C}\right)$ & $\mathrm{P}$ & Total phosphorus (ppm) \\
Tcld & Coldest quarter mean temperature $\left({ }^{\circ} \mathrm{C}\right)$ & $\mathrm{P}\left(\mathrm{HCO}_{3}\right)$ & Available phosphorus $(\mathrm{ppm})$ \\
Twar & Warmest quarter mean temperature $\left({ }^{\circ} \mathrm{C}\right)$ & $\mathrm{CaCO}$ & Calcium Carbonate $(\%)$ \\
Tdi & Temperature diurnal range $\left({ }^{\circ} \mathrm{C}\right)$ & $\mathrm{CEC}$ & Cation exchange capacity $(\mathrm{me} \%)$ \\
Tar & Temperature annual range $\left({ }^{\circ} \mathrm{C}\right)$ & tx-shst & Soil textural shear strength $(\mathrm{kPa})$ \\
Cst-dist & Distance to coast $(\mathrm{km})$ & $\mathrm{Stone}$ & Amount of rock in soil profile \\
Alt & Altitude $(\mathrm{m})$ & Sand & Percent sand \\
Lat & Latitude $\left({ }^{\circ} \mathrm{S}\right)$ & $\mathrm{gs}-\mathrm{over}$ & Over-bank stream flow \\
Long & Longitude $\left({ }^{\circ} \mathrm{E}\right)$ & & \\
\hline
\end{tabular}

